\title{
Viral Hepatitis B: Seroprevalence and Genetic Diversity in Blood Donors North of Congo
}

\author{
Mongo-Onkouo Arnaud1,2, Dzia Lepfoundzou Amelia², Dinghat Ornela Marlyne Yvonne³, \\ Ahoui Apendi Clausina Philestine ${ }^{1,2}$, Mimiesse Monamou Jile Florent ${ }^{1,2}$, \\ Itoua-Ngaporo Ngala Akoa1,2, Ngami Rody Stéphane1, Ngalessami Mouakosso Marlyse1,

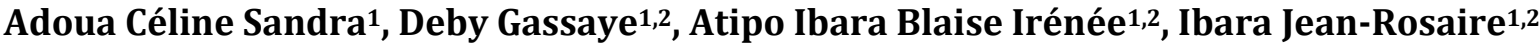

\footnotetext{
${ }^{1}$ Department of Hepatogastroenterology and Internal Medicine Of Brazzaville Universty Hospital Center, Brazzaville, Congo ${ }^{2}$ Faculty of Health Sciences, Marien Ngouabi University, Brazzaville, Congo

${ }^{3}$ Department of Metabolic Diseases of Brazzaville University Hospital Center, Brazzaville, Congo

Email: mongoonkouo@gmail.com
}

How to cite this paper: Arnaud, M.-O., Amelia, D.L., Yvonne, D.O.M., Philestine, A.A.C., Florent, M.M.J., Akoa, I.-N.N., Stéphane, N.R., Marlyse, N.M., Sandra, A.C., Gassaye, D., Irénée, A.I.B. and Jean-Rosaire, I. (2019) Viral Hepatitis B: Seroprevalence and Genetic Diversity in Blood Donors North of Congo. Open Journal of Gastroenterology, 9, 239-245.

https://doi.org/10.4236/ojgas.2019.912027

Received: October 21, 2019

Accepted: November 26, 2019

Published: November 29, 2019

Copyright () 2019 by author(s) and Scientific Research Publishing Inc. This work is licensed under the Creative Commons Attribution International License (CC BY 4.0).

http://creativecommons.org/licenses/by/4.0/

\section{cc) (7) Open Access}

\begin{abstract}
Introduction: Viral hepatitis B is the most formidable and confusing of all viral hepatitis, given its cirrhogenic and carcinogenic potential. The objective of the study is to characterize the molecular profile of hepatitis virus B in northern Congo. Materials and Methods: This was a descriptive and cross-sectional study that was carried out between January and September 2014, that is 9 months, in the establishments of the National Center for Blood Transfusion (CNTS) of the 4 departments of the north of the Congo. Epidemiological, serological and molecular variables (HBsAg, HBV DNA, genotypes and subtypes) were studied. The HBs antigen was searched by rapid test and confirmed by ELISA. For all positive donors, conventional and specific gene extraction and amplification techniques were performed for the identification of genotypes and subtypes from the serum. Results: A total of 892 donors were included. The average age was $35.36 \pm 12.36$ years with extremes ranging from 18 to 65 years old. The sex ratio $(M / F)$ was 3.3. The prevalence of HBV was $8.6 \%$. The viral DNA of HBV was amplified in $83.1 \%$. Four genotypes were found: E (40.6\%), A (3.1\%), B (3.1\%) and C (1.6\%). Two cases of co-infection were identified: $\mathrm{E} / \mathrm{A}(15.6 \%)$ and $\mathrm{B} / \mathrm{C}(1.6 \%)$. Subgenotypes $\mathrm{A} 1, \mathrm{~B} 2$ and $\mathrm{C} 1$ were highlighted. Conclusion: The prevalence of $\mathrm{HBV}$ is high, $\mathrm{HBV}$ infection remains a major public health problem for blood donors in Congo. Genotypes E, A, B, C as well as subtypes A1, B2, C1 have been identified in northern Congo.
\end{abstract}

\section{Keywords}

HBV, Molecular Biodiversity, Subgenotypes, North Congo 


\section{Introduction}

Infection with the hepatitis B virus is a major health problem in the world. It is estimated that about 400 million chronic carriers of hepatitis B virus (HBV) and more than one million deaths annually [1] [2] worldwide. In Africa, it is estimated that about 100 million people are infected with HBV [1]. In Congo, the prevalence of HBV carriage among blood donors is $7.8 \%$ with unequal distribution throughout the country [2]. The departments of southern Congo (Bouenza, Pointe-Noire, and Niari) are considered hyper-endemic areas for HBV. The identification of HBV reduces the risk of transmission and improves blood transfusion safety. The genetic diversity of HBV makes it necessary to identify HBV genotypes because HBV genotype research in recent years has shown significant associations between HBV genotypes and the severity of HBV, clinical outcomes, and response to antiviral treatments [3]. Several genotypes have been identified in the world, they are classified from $A$ to $J$ and have a distinct geographical distribution. In Congo, genotypes $\mathrm{A}$ and $\mathrm{E}$ are the most common [2] [4]. But, these data are incomplete and do not concern all departments. The aim of the study is to characterize the molecular profile of $\mathrm{HBV}$ in blood donors in northern Congo.

\section{Materials and Methods}

It was a descriptive and cross-sectional study that ran from January 1st 2014 to September 30th 2014, is a period of 9 months. The study was carried out in Congo in the establishments of the Interdepartmental Center of Blood Transfusion (CIDTS) of the northern zone of the country located in the following departments: the Plateaux (Gamboma), the Central Cuvette (Owando, Boundji, Oyo), the West Bowl (Ewo) and the Sangha for sample collection. The serological and molecular analyzes were carried out in Morocco in the Laboratory of Virology and Microbiology Quality/Ecotoxicology and Biodiversity (LVMQ/ETB) of the Faculty of Science and Technology (FST) of Mohammedia-Casablanca, Hassan II University. The transport was carried out as follows; first by car, in a cooler containing cold accumulators of the various post blood transfusion to the CIDTS of Owando, then Owando to national blood transfusion center (CNTS) of Brazza city on a distance of $510 \mathrm{~km}$ for 7 hours. All these samples were analyzed in Brazzaville. Then we transported the samples from Brazzaville to Mohammedia (Morocco) by air in the hold, in dry ice after $\mathrm{CO}_{2}$ bombardment, for 8 hours and stored at $-20^{\circ} \mathrm{C}$ until analysis. The choice of health structures that served as a survey frame was random. The study population consisted of occasional, regular and family blood donors in the different study centers. Included were all donors between the ages of 18 and 65 who consented to the study and were considered fit to donate blood. Nonconsenting donors and all those with inoperable sera (denaturation) either by default of storage or by default of transport of sera were excluded from the study. Sociodemographic, biological (HBsAg, HBV DNA, HBV genotype) and 
risk factors for $\mathrm{HBV}$ transmission were studied. Serological analysis was performed from the serum stored at $-20^{\circ} \mathrm{C}$. The fourth-generation ELISA technique allowed the detection of AgHbs using the Monolisa HBs Ag ULTRA brand BIORAD reagent. All HBsAg positive samples were molecularly tested using the QIAGEN QIamp DNA blood kit. DNA extraction was carried out on the HBV S surface gene from the HBPol primer pairs of the PreS1/PreS2/HBsAg, HBPr1/ HBPr135 and HBPr2/HBPr3 domains. All samples positive for nested PCR were genotyped using the type-specific PCR method (TS-PCR) as described by Naito et al. [5]. Data development and processing were done with CSPRO 5.1, Excel, 2013 and SPSS 21. The proportions were compared with an appropriate Chi-square statistical test (X2) with a significance threshold $\mathrm{p}<0.05$.

\section{Results}

At the end of this survey, 892 blood donors were collected and distributed as follows: 320 (35.9\%) to Owando; 173 (19.4\%) in Gamboma; 141 (15.8\%) in Ouesso; 133 (14.3\%) at Ewo; $92(10.3 \%)$ at Oyo; 33 (3.7\%) at Boundji.

Family donors accounted for $67.9 \%$ (606 donors) of the study population. There were 197 (22.1\%) regular donors and 89 (10\%) volunteer donors. The average age of our study population was $35.36 \pm 12.36$ years with extremes ranging from 18 to 65 years old. Male donors accounted for 61.1\% (545/892), while females accounted for $38.9 \%$ (347/892). The sex ratio was 1.57 or 157 men per 100 women (Table 1 ).

Unsafe sex, circumcision, and multiple sexual partners were the most common risk factors for transmission (Table 2). Of the 892 donors screened, 77 were positive for HBsAg, which is $8.6 \%$. There were 61 (79.2\%) family donors, 11 (14.3\%) regular donors and 5 (6.5\%) volunteer donors. Parmi les 77 échantillons positifs à l'AgHBs et soumis à l'étude moléculaire, 64 se sont révélés positif à l'ADN viral du VHB après $\mathrm{PCR}$ nichée. The overall molecular prevalence of $\mathrm{HBV}$ infection was $83.1 \%$. Genotype A and co-infection E/A prevail (Table 3); the subgenotypes $\mathrm{A} 1, \mathrm{~B} 2$ and $\mathrm{C} 1$ have been identified in identical ways.

Table 1. Distribution of patients by age group by gender.

\begin{tabular}{ccccccc}
\hline \multirow{2}{*}{$\begin{array}{c}\text { Sex } \\
\text { Age }\end{array}$} & \multicolumn{2}{c}{$\mathrm{M}$} & \multicolumn{3}{c}{$\mathrm{F}$} & \multicolumn{2}{c}{ Total } \\
\cline { 2 - 7 } & Effective & $\%$ & Effective & $\%$ & Effective & $\%$ \\
\hline 25 & 138 & 15.5 & 87 & 9.8 & 225 & 25.2 \\
$25-34$ & 140 & 15.7 & 90 & 10.1 & 230 & 25.8 \\
$35-44$ & 131 & 14.7 & 69 & 7.7 & 200 & 22.4 \\
$45-54$ & 109 & 12.2 & 79 & 8.9 & 188 & 21.1 \\
$\geq 55$ & 27 & 3.0 & 22 & 2.5 & 49 & 5.5 \\
Total & $\mathbf{5 4 5}$ & $\mathbf{6 1 . 1}$ & $\mathbf{3 4 7}$ & $\mathbf{3 8 . 9}$ & $\mathbf{8 9 2}$ & 100 \\
\hline
\end{tabular}

Khi2 $=3.152 ; \mathrm{P}=0.533>0.05$. 
Table 2. Risk factors of the study population.

\begin{tabular}{ccc}
\hline Factor of risk & Effective & Percentage \\
\hline Sexual risk ratio (unprotected) & 211 & 23.7 \\
Circumcision & 280 & 20.2 \\
Multiple sex partners & 115 & 12.9 \\
Scarification & 99 & 11.9 \\
Dental care & 50 & 5.6 \\
Tatoo & 47 & 5.3 \\
Surgical intervention & 35 & 3.9 \\
Piercing & 25 & 2.8 \\
Transfusion & 18 & 2.0 \\
Accidental injury with sampling needle & 14 & 1.6 \\
Partner Drug addict & 7 & 0.8 \\
Invasive exposure (endoscopy with or without biopsy) & 5 & 0.6 \\
IV drug use & 3 & 0.3 \\
Mother infected with hepatitis B & 1 & 0.1 \\
\hline
\end{tabular}

Table 3. HBV genotyping results by specific PCR.

\begin{tabular}{ccc}
\hline AgHBs Positive Genotypes & Effective & Percentage \\
\hline E & 26 & 40.6 \\
E/A & 10 & 15.6 \\
A & 2 & 3.1 \\
B & 2 & 3.1 \\
C & 1 & 1.6 \\
B/C & 1 & 1.6 \\
Not determined & 22 & 34.4 \\
Total & 64 & 100 \\
\hline
\end{tabular}

\section{Discussion}

The collection of samples in our study was done in a fixed cabin, that is to say in place of each blood establishment. This method makes it possible to avoid staining and confusion of the samples. The high prevalence of HBsAg in our series confirms Congo's place among the highly endemic countries of hepatitis B as reported by Atipo Ibara and al [2]. This prevalence can be explained by the absence of a policy to reduce the transmission of hepatitis viruses; Congo does not have a program to fight viral hepatitis [6]. The establishment of a viral hepatitis control program would fill the lack of information on the viral hepatitis $B$ virus and the lack of popularization of the means of prevention against this virus. Similarly, immunization of HBV seronegative donors would be a better weapon against this infection. The prevalence of $\mathrm{HBsAg}$ is variously appreciated in the literature. It seems higher in the work already done in the Congo and in 
our study but weaker in the work done by some African authors [2] [7] [8]. Depending on the type of donation, our study showed a significantly higher prevalence in family or replacement donors. This difference in prevalence could be explained by the loyalty efforts of regular and occasional donors. This supports the hypothesis that regular donors are at low risk of transmitting diseases through blood transfusion to the extent that they receive information about the importance of blood safety and are screened for each blood donation. However, despite CNTS's efforts to retain regular donors, our study reveals that $14.3 \%$ of regular donors carry HBsAg. This result could be explained by the serological window of HBV. This window, which is immunologically silent, separates the date of the contamination from the one in which the HBV markers appear, which justifies the negativity of the tests at this period, hence the interest of the PCR. Indeed, for Kone et al., the safety of blood transfusion would be ensured by strategies that should be directed towards the abandonment of family blood donation such as the promotion of volunteer donation, loyalty and the organization of donors in clubs [9]. Naila et al. claim that in Pakistan the risk of HBV transmission is higher among replacement donors (family) because this category is in fact associated with poor people, who are secretly paid by the family and who conceal information during the selection interview [10]. We found a significant difference between the carriage of HBsAg and the risk factors for transmission found in the study. Several authors make the same observation [11] [12]. Molecular biology techniques, long reserved for the field of research in sub-Saharan Africa, contribute qualitatively to the improvement of screening in blood transfusion. DNA is a marker of viral replication, those with a molecular signature are a reservoir of the virus and have a higher risk of developing chronic hepatitis and/or cirrhosis and/or hepatocellular carcinoma [2]. We found the $\mathrm{E}, \mathrm{A}, \mathrm{B}, \mathrm{C}$ genotypes with a predominance of the $\mathrm{E}$ genotype. However, we noted the associations between the E/A and B/C genotypes. Our results are consistent with those found by Atipo Ibara et al. in a study conducted in southern Congo [2]. These results are in agreement with the literature, which states that genotype A is ubiquitous, predominating in northwestern Europe and central Africa [13]. The same is true for genotype E, which is more common in Central Africa and West Africa [14] [15]. The particularity of this study is the discovery of genotypes B and C that do not exist in southern Congo. However, genotypes B and C are mainly found in Asia and the Pacific Islands [16]. Their presence in northern Congo could be linked to the mixing of populations. Thus genotypes $\mathrm{B}$ and $\mathrm{C}$ would be import strains. The other particularity in the study is the identification of subtypes of HBV, in particular the subgenotypes A1, B2 and $\mathrm{C} 1$. However, given the very small number of sequences analyzed, we can not accurately define the sub-genotypes circulating in this area of the country. However, this preliminary result provides an overview of the epidemiological profile of genotypes and HBV genotypes in blood donors in our study population and can serve as a guideline in the development of transfusion safety 
strategies in Congo.

\section{Conclusion}

The present study reveals that $\mathrm{HBV}$ is common among blood donors in the departments of Plateaux, Central Basin, West Cuvette and Sangha in northern Congo. These results are consistent with the previous study in the south of the country, which places Congo in the zone of high HBV endemic countries. We identified the genotypes A, B, C, E as well as the subgenotypes A1, B1, C1. The high frequency of HBV as well as its genotypic variability justify the establishment of a genomic denomination of blood donations in order to improve transfusion safety.

\section{Conflicts of Interest}

The authors declare no conflicts of interest regarding the publication of this paper.

\section{References}

[1] Lemoine, M, Eholié, S. and Lacombe, K. (2015) Reducing Neglected Burden of Viral Hepatitis in Africa: Stratégies of the Global Approach. Journal of Hepatology, 62, 469-476. https://doi.org/10.1016/j.jhep.2014.10.008

[2] AtipoIbara, B.I., Itoua-Ngaporo, A.N., Dzia-Lepfoundzou, A., Ahoui-Apendi, C., Bossali, F., et al. (2015) Hepatitis B Virus in Congo (Brazzaville): Seroprevalence and Genetic Diversity in Blood Donors in Hyper-Endemic Areas. Journal Africain d?Hépato-Gastroentérologie, 9, 127-131.

[3] Ntagirabiri, R., Munezero, B., Nahimana, C. and Ndabaneze, E. (2016) Hepatitis B Virus Genotypes and Evolutionary Markers of Chronic HBsAg Carriers in Bujumbura. Pan African Medical Journal, 23, 95. https://doi.org/10.11604/pamj.2016.23.95.8424

[4] Naito, H., Hayashi, S. and Abe, K. (2001) Rapid and Specific Genotyping System for Hepatitis B Virus Corresponding to Six Major Genotypes by PCR Using Type-Specific Primers. Journal of Clinical Microbiology, 39, 362-364. https://doi.org/10.1128/JCM.39.1.362-364.2001

[5] Mbendi Nlombi, C., Longo-Mbenza, B., Mbendi Nsukini, S., Muyembe Tamfum, J.J., Situakibibanza, H., et al. (2001) Prevalence of HIV and HBsAg in Blood Donors. Residual Risk of Contamination in Blood Recipients in East Kinshasa, Democratic Republic of Congo. Medecine tropicale, 61, 139-142.

[6] Mongo-Onkouo, A., Itoko Okombi, R., Boumba, A., Niam, F.R., Ahoui Apendi, C.P., Mimiesse, J.F., et al. (2018) Seroprevalence and Molecular Biodiversity of Hepatitis B and Delta Virus Infections in the Republic of Congo. Open Journal of Gastroenterology, 8, 448-454. https://doi.org/10.4236/ojgas.2018.812046

[7] Noubiap, J.J.N., Walburga, Y.A.J., Nansseu, J.R.N., Tene, U.G. and Siaka, C. (2013) Sero-Epidemiology of Human Immunodeficiency Virus, Hepatitis B and C Viruses, and Syphilis Infections among First-Time Blood Donors in Edéa, Cameroon. International Journal of Infectious Diseases, 17, 832-838. https://doi.org/10.1016/j.ijid.2012.12.007

[8] Namululi, B.A., Guerrieri, C. and Dramaix, M.W. (2013) Prevalence and Incidence of HIV and Hepatitis B in Blood Donors and Estimation of the Residual Risk of 
Transmission of HIV and HBV by Blood Transfusion. A Study at the Provincial General Reference Hospital of Bukavu, Democratic Republic of Congo. Journal of Epidemiology and Public Health, 61, 139-144.

[9] Koné, M.C., Sidibé, E.T., Malle, K.K. and Diara, M.T. (2012) Seroprevalence of Human Immunodeficiency Viruses and Hepatitis B and C in Blood Donors in Segou, Mali. Médecine et Santé Tropicales, 22, 97-98.

[10] Naila, A., Nasir, K. and Fazal, I. (2001) Seroprevalence of HBV, HCV and HIV Infection among Voluntary Non Remunerated and Replacement Donors in Northern Pakistan. Pakistan Journal of Medical Sciences, 20, 24-28.

[11] Liaw, Y.F. and Chu, C.M. (2009) Hepatitis B Virus Infection. The Lancet, 373, 382-392. https://doi.org/10.1016/S0140-6736(09)60207-5

[12] Sidibe, S., Youssoufi Sacko, B. and Traoré, I. (2001) Prevalence of Serologic Markers of Hepatitis B Virus in Pregnant Women in Bamako District, Mali. Bulletin de la Societe de pathologie exotique, 94, 339-341.

[13] Kurbanov, F., Tanaka, Y. and Mizokami, M. (2010) Geographical and Genetic Diversity of the Human Hepatitis B Virus. Hepatology Research, 40, 14-30. https://doi.org/10.1111/j.1872-034X.2009.00601.x

[14] Wagner, A., Denis, F., Ranger-Rogez, S., Loustaud-Ratti, V. and Alain, S. (2004) Genotype du Virus de l'hepatite B. Immuno-Analyse \& Biologie Spécialisée, 19, 330-342. https://doi.org/10.1016/j.immbio.2004.10.002

[15] Norder, H., Courouce, A.M., Coursag, P., Echevarria, J.M., Lee, S.D., Mushahwar, I.K., et al. (2004) Genetic Diversity of Hepatitis B Virus Strains Derived Worldwide: Genotypes, Subgenotypes, and HBsAg Subtypes. Intervirology, 47, 289-309. https://doi.org/10.1159/000080872

[16] Chan, H.L., Wong, G.L., Tse, C.H., Chan, H.Y. and Wong, V.W. (2011) Viral Determinants of Hepatitis B Surface Antigen Seroclearance in Hepatitis B e Antigen-Negative Chronichepatitis B Patients. The Journal of Infectious Diseases, 204, 408-414. https://doi.org/10.1093/infdis/jir283 